\title{
The Impact of AAOIFI Governance Disclosure on Islamic Banks Performance
}

\author{
Tawida Elgattani \\ Visiting Academic, Portsmouth Business School, University \\ of Portsmouth \\ tawida.elgattani@port.ac.uk

\begin{abstract}
Khaled Hussainey
Professor of Accounting and Financial Management, Portsmouth Business School, University of Portsmouth khaled.hussainey@port.ac.uk
\end{abstract}

Acknowledgement:

This paper is a slightly revised version of Chapters 3 and 7 of a Ph.D. thesis entitled: "AAOIFI governance disclosure in Islamic banks: Its determinants and impact on performance" by the first author of the paper (Tawida Elgattani) submitted to the Accounting and Financial Management Division, Portsmouth Business School, the University of Portsmouth (December 2018). Tawida would like to thank the supervisory team (Professor Khaled Hussainey and Dr. Antonios Kallias and the examiners (Professor Mehmet Asutay and Dr. Ahmed Aboud) for their valuable comments on earlier versions of her thesis. The authors of the current paper confirm that there is no any copyright issue associated with their work. 
Purpose- This study aims to investigate the impact of the Accounting and Auditing Organisation for Islamic Financial Institution (AAOIFI) governance disclosure on the performance of Islamic Banks (IBs).

Design/methodology/approach- The OLS regression model was used to test the impact of AAOIFI governance disclosure on the performance of $126 \mathrm{IBs}$ from eight countries that mandatorily adopt the AAOIFI standards for three years (2013-2015). In this regression model, return on asset and return on equity are the dependent variables, while AAOIFI governance disclosure is the independent variable. Corporate governance mechanisms, firm characteristics, year dummy, and country dummy are used as control variables.

Findings- We found an insignificant relationship between AAOIFI governance disclosure and IBs performance.

Research limitations/implications- The study highlighted the implication that the current research may help IBs and encourage them to disclose more information in annual reports, especially those related to AAOIFI governance standards because following good CG leads to good financial performance. The major limitation of the paper is that it is only focused on two measurements of bank performance - ROA and ROE; it would be good to employ other firm performance measures, such as profit margin.

Originality/value- This research provides new empirical evidence on the impact of AAOIFI governance disclosure on IBs performance.

Keywords- AAOIFI Governance, Islamic Banks performance, return on asset and return on equity

\section{Introduction}

Over the past three decades, Islamic economics has been growing and today there are more than 250 financial institutions across 45 countries (Magalhaes and Al-Saad, 2013). Nowadays, IBs are the higher proportion of Islamic Financial Institutions (IFIs), extending locally and internationally over both Muslim and Western countries (Sarea and Hanefah, 2013). According to Abdullah et al. (2015), the percentage of assets of IBs around the world enlarged with an annual increase rate of about 17\% from 2009 to 2013. Also, these assets in six core markets will reach the US $\$ 1.8$ trillion by 2019 . "This growth not only relates to assets but also the products covered, this growth has outstripped corresponding developments in a complementary regulatory framework, necessitated by the unique characteristics of some Islamic contract" (Vinnicombe, 2012: 78 ).

According to Chazi et al., (2018) following good CG leads to good financial performance, reduces the internal risk and increases the strength and resilience of institutions to external stakeholders. Shahid et al., (2018) claim that it can guarantee a higher level of access to financing standards, reduces capital cost and produces a good working relationship with all stakeholders by having good CG structures.

In the modern world, IBs aim to enhance and improve the enforcement of the principles of Islamic law to all banking transactions, to make all stakeholders guarantee that all banking transactions are consistent with Sharia law (Paino et al., 2011). Disclosure in IFIs may decrease information asymmetry owing to the particular contracts among IBs and their stakeholders (Neifar, 2020). To increase stakeholders trust in the IFIs system, IBs should have a good CG strucure that guarantees and shows Sharia compliance in all their transactions (Srari, 2015).The compliance with Sharia principles is the important feature of 
IBs that is confirmed to stakeholders by the Sharia supervisor Board (SSB) in their report (Albarrak and EL-Halaby, 2019).

There have been some previous studies in the relationship between CG and firm peformance (Albarrak and El-Halaby, 2019). However, these studies have not examined the impact of AAOIFI governance on IBs performance. This paper is an extension of prior research (Elgattani and Hussainey, 2020) that studied the determinants of AAOIFI governance disclosure in IBs; this study focuses on the impact of AAOIFI governance disclosure on IBs. Therefore, this paper seeks to fill the gap by investigating the influence of AAOIFI governance disclosure on IB's performance.

In this paper we aim to make new contributions to the extant literature in a number of ways. Firstly, we study all IBs that adopt AAOIFI standards mandatorily. Secondly, we are the first study that considers all AAOIFI governance standards. Thirdly, we are the first to examine the consequences of AAOIFI governance disclosure on the return on asset (ROA), and return on equity (ROE) for IBs. Our findings provide practical implications to IBs and AAOIFI members.

The remainder of the paper is structured as follows: Section 2 reviews the literature; Section 3 discusses the methodology; Section 4 presents the findings; Section 5 concludes.

\section{Literature Review}

According to Klapper and Love (2004), a good CG mechanism will lead to higher process performance and higher firm performance. Furthermore, an optimal CG mechanism raises the internal safeguard and will ensure the trust of investors regarding their investment (Zhang, 2012). After the establishment of the AAOIFI in 1990, to 2018, more than 100 standards have been issued (Sarea, 2020). The AAOIFI has provided guidelines on Sharia governance by publishing seven standards. The main aim for the establishment of these standards is to confirm the efficient function of the IFIs' system, to encourage transparency and to make sure that, for all stakeholders, the IFIs comply with Sharia by following good CG (Bahari and Baharudin, 2016).

The influence of a good corporate mechanism on firm performance shows mixed results. For example, Nelson (2005), demonstrated that a higher quality of CG positively impacts firm performance. Similarly, Bhatt and Bhatt (2017), analysed the CG framework impact of firm performance on 113 listed firms in Malaysia, and they found that firm performance is positively and significantly linked with CG. Also, Al-Ataibi (2017) investigated the extent of the impact of the principles of governance on improving firm performance. The study found that there is an influence of governance on developing firm performance. Al-Najjar (2014) explored the relationship between CG and firm performance in five countries in the Middle East. The study found that board independence positively impacts firm performance. Anis et al. (2017), investigated the impact of board characteristics on a firm's financial performance. They studied 70 firms over six years, from 2005 to 2010, and the sample included the most active companies listed on the Egyptian stock market. The study found that firm size is statistically significant with ROA and the age of the firm is statistically significant with market performance, measured using Tobin's Q. In contrast the CEO and firm accounting performance had a negative relationship. Additionally, Garefalakis et al. (2017) investigated the effect of CG information on bank performance. The study found that board independence strongly supports bank efficiency and operations.

Almoneef and Samontaray (2019) examined the impact of CG on Saudi banking performance from 2014 to 2017. The study found that board size, audit committee meeting and bank size have a positive impact with ROA and ROE. Also, Shahid et al.(2018) investigated the effect of CG systems on firm performance on 58 companies in Pakistan 
during the period of 2007 to 2010 . The study found that board size has an insiginificant positive assocation with ROE.

Harisa et al. (2019) examined the effect of the quality of good CG disclosure on IBs performance in Indonesia and Malaysia over the period 2011-2017. The research showed that the quality of good CG had an effect on bank performance. Recently, Neifar et al. (2020) investigated the impact of board effectiveness on financial performance in 25 IBs in GCC countries during 2008-2017. The research found that there is a positive moderating effect of sharia supervisor board quality on association between performance and board effectivness.

In contrast, Hassan et al. (2016) examined the association between CG mechanisms and financial performance in all non-financial companies listed on the Palestinian stock exchange during 2010 and 2012. The study found that corporate performance is negatively associated with CG. Similarly, Pearce and Patel (2017), found that board independence is not associated with firm performance and CEO is negatively associated with firm performance. Detthamrong et al. (2017), examined the association between CG and firm performance in 493 non-financial firms in Thailand between 2001 and 2014. The study found that $\mathrm{CG}$ is not associated with firm performance.

Almenef and Samontaray (2019), also found board independence has a negative impact on Saudi banking performance and number of board committee; bank age has a negative association with bank performance measured by Tobin's Q.

Recently, there has been some attention on the study of AAOIFI governance such as (Elgattani and Hussainey, 2020) who study the impact of CG mechanism on AAOIFI governance disclosure in IBs during the period 2013-2015. The study found that the audit committee size is the major determinant of the AAOIFI governance disclosure however they did not focus on the impact of AAOIFI governance on IBs performance. Therefore, the motivation of the current study was to focus on the impact of AAOIFI governance on IBs performance, to fill this gap in the literature.

As far as the researchers know, there is no prior study on the effect of AAOIFI governance disclosure on IBs performance. Thus, the current research examines this issue. According to the above discussion, the current research hypothesises that:

\section{$\mathrm{H}_{1}$ : There is a relationship between the level of AAOIFI governance disclosure and IBs performance.}

\subsection{Corporate governance mechanisms and firm-specific characteristics (control} variables)

Based on relevant theories and literature, we have considered CG mechanisms and firmspecific characteristics as control variables.

\subsubsection{Independent directors and bank performance}

According to agency theory, independent directors help to reduce agency problems between agents and principals (Fama, 1980). Additionally, from signalling theory, "the presence of independent members on the board can serve as a signal to the existence of fewer agency problems" (Black et al., 2006). Fama and Jensen, (1983) argue that independent directors, with their expertise and connections to a firm, can then improve firm value. Moreover, Goodstein et al. (1994) suggest that the monitoring increases and affects firm value through a high number of independent directors. 
Empirical studies have found mixed results between independent directors and firm performance. A positive relationship is noted by Al-Najjar (2014), who explored the relationship between $\mathrm{CG}$ and firm performance in tourism companies. They found that board independence is found to be positively related to firm performance as measured by ROA. Similarly, using 27 IBs in five Arab Gulf countries for three years (2011-2013), Srairi (2015) found that the IBs with a high level of CG disclosure report a high level of performance measured by ROA and ROE. Also, Anis et al. (2017) studied the impact of board characteristics on bank performance using a sample of 70 firms over six years. They found a positive association between the independent board and bank performance. Furthermore, ( Pearce and Patel, 2017 and Garefalakis et al., 2017) found a positive relationship between the two variables.

On the other hand, Bozec (2005), investigated 25 Canadian companies from 1976 to 2000, measured by ROA, return on sales and Tobin's Q; the study found that firm value was lower in companies that had a board dominated by independent board members. Al-Maghzom et al. (2016) and Molnar et al. (2017) found no significant association between the two variables.

\subsubsection{Board size and bank performance}

Agency theory suggests that a larger board may have increased managerial costs, which then negatively affect firm value (Yawson, 2006). For instance, a large board may increase board expenses, remuneration and other allowances. A larger board can lead to an increase in agency costs and reduce the firm value (Jensen and Meckling, 1976).

Previous studies found mixed results between board size and firm performance. Gordon et al. (2012), suggested that more efficient CG practices are related to board size, which positively affect financial performance. Similarly, a larger board may attract more qualified members who may improve board decisions (Yawson, 2006). Al-Najjar (2014), found that large boards increase firm profitability. However, small boards show a greater level of efficiency in the stock market. Also, (Hussain and Hadi, 2017 and Taherian and Karampour, 2017 ) found a positive relationship between the two variables.

In contrast, some studies found the relationship between board size and firm performance is negative and insignificant, such as Amoateng et al. (2017), who studied the impact of CG practices on the performance of SMEs in Ghana. They found that board size has a negative and insignificant impact on firm performance. Similarly, (Hassan et al., 2016 and Pearce and Patel, 2017) found an insignificant negative association among the two variables.

\subsubsection{Frequency of directors meetings' and bank performance}

The main responsibility of a board director is monitoring the firm's operation (Mahadeo et al., 2012 and Khan et al., 2013). Hence, regular board meetings lead to good monitoring by managers (Vafeas, 1999). Regular board meetings can increase firm performance by relieving agency problems (Schwartz-Ziv and Weisbach, 2013).

The existing literature on the association between the frequency of board meetings and firm performance is mixed. According to Schwartz-Ziv and Weisbach (2013), the relationship between the frequency of board meetings and financial performance is positive. According to agency theory, this may reduce conflicts and help to influence shareholders positively. Upadhyay et al. (2014) found a positive relationship between the two variables by using a sample of US firms. Similarly, Albassam (2014), pointed to a positive relationship between the frequency of board meetings and performance. Also, Chou and Buchdadi (2017), 
examined the impact of board meetings on banking practice in Indonesia. They found that board meetings enhance the operational performance of the bank.

On the other hand, Vafeas (1999) states that a high frequency of board meetings can increase agency costs. For example, travel expenses and meeting expenses can have a negative effect on firm value (Fama and Jensen, 1983). Fich and Shivdasani (2006), also found that the frequency of board meetings had a negative effect on firm value. Similarly, Christensen et al. (2015) found the same result. Also, Hassan et al. (2016), found a negative relationship between the two variables.

\subsubsection{CEO duality and bank performance}

Agency theory proposes that CEOs should run the firm in the best interest of shareholders (Jensen and Meckling, 1976). Jensen (1993) and Blackburn (1994), argue that merging the roles of chairperson and CEO may undermine the board's controlling power.

White and Ingrassia (1992) assert that CEO duality can lead to a decline in performance because of the agency cost if the CEO practices their interest at the expense of the shareholder. CEO duality is an essential dimension of governance which affects firm performance (Mollaha and Zamanb, 2015). According to agency theory, CEOs should manage a firm in the best interests of shareholders (Chen et al., 2011). Mollaha and Zamanb (2015), investigated the impact of CEO power on financial performance during the period 2005-2011. They found a negative impact on firm value.

Similarly, Mashayekhi and Bazaz (2008), argued that CEO duality could present self-serving opportunities to control board meetings that may have a negative effect on corporate financial performance. Similarly, Anis et al. (2017) found a negative relationship between CEO duality and firm performance. Also, Albassam (2014), found a negative impact on the two variables.

On the other hand, Boyd (1995), found that CEO duality leads to a higher return on investment. Also, (Pearce and Patel, 2017 and Scafarto et al., 2017) found a positive relationship between CEO duality and firm performance. In addition, (Garefalakis et al., 2017 and Hussain and Hadi, 2017) found a significant association between the two variables. Some research studies found that CEO duality does not affect firm value, such as Bozec (2005), who found the insignificant impact of CEO duality on firm value in a sample of 25 Canadian firms between 1976 and 2000.

\subsubsection{Audit committee size and bank performance}

ACs enforcement plays a vital role to ensure adequate CG to all stakeholders (Velte, 2017). Agency theory proposes that ACs decrease the conflict of interest and asymmetric information between management and investors (Jensen and Meckling, 1976). Zhang et al. (2007), stated that ACs is still valued as one of the essential governance characteristics that are recommended for developed governance accountability, transparency and reporting quality in firms. Most of the prior studies suggest that firms that employ large audit firms tend to have a high level of agency conflicts, and they aim to decrease the existing level of conflict through the staffing of external firms (Inchausti, 1997).

Chan and Li (2008) investigate the impact of ACs on the firm value of 200 firms and found a negative association between the two variables. Similarly, Detthamrong et al. (2017) examined the association between CG and firm performance for a panel of 493 firms in Thailand during the period 2001-2014. They found that ACs had a negative effect on firm 
performance. Also, Hassan et al., (2016), found a negative association among the two variables.

\subsubsection{Firm characteristics and bank performance}

Following previous studies (Aggarwal et al., 2008; Harun, 2017; Al-Najjar and Al-Najjar, 2017; Bravo and Reguera-Alvarado, 2017) the current study considers some firm characteristics, these controls are firm size, liquidity, leverage and firm asset growth.

Al-Akra and Ali (2012) assert that firm size impacts on firm value because larger firms find it easier to obtain sources of funding. Also, significant total assets can be used internally as sources for the firm, and managers have more flexibility in using assets, as a result there is an improvement in firm performance and an increase in firm value Ezat and El-Masry, (2008). So, in previous studies, such as Hassan et al. (2009), a positive relationship is seen between company size and performance. Similarly, Bravo and Reguera-Alvarado (2017), also found this positive association, as did Anis et al. (2017). Thus, the larger firm is usually expected to have a better value, especially regarding firm performance (Samaha et al., 2012).

Liquidity is another variable that can affect firm performance. From a signalling theory perspective, companies with high liquidity tend to highlight their positive liquidity outcomes to indicate their abilities to investors. Also, agency theory confirms the relationship between liquidity and firm performance. Prior studies found a significant positive relationship between liquidity and operation standards (White and Ingrassia, 1992). In contrast, AlMaghzom et al. (2016) found a negative association between liquidity and firm value.

Regarding leverage, this might have a positive influence on bank performance. According to Hodgson and Stevenson-Clarke (2000), this effect might take place because tax deductibility on borrowing may result in a reduction in the cost of capital, which greatly raises company performance. In previous studies, there are mixed results for the association between firm value and leverage. Companies with rising leverage seek to have great operations to obtain higher profit growth (Ouma, 2012). Also, Pillai and Al-Malkawi (2017) found a significant relationship between leverage and firm performance. Meanwhile, some previous studies found a negative association between leverage and firm value (Bravo and Reguera-Alvarado, 2017; Hassan et al., 2016; Harun, 2017).

Firm asset growth is related to the existence of firms because company growth is related to a rise in work actions (Henry, 2008). According to Henry (2008), firms may receive a good valuation with better growth opportunities. Empirically, prior studies have found a significant relationship between company growth and bank performance (Henry, 2008; Haniffa and Hudaib, 2006).

Furthermore, country and year dummy variables are included as control variables to indicate the absence or presence of some crucial impact that we expect will probably shift the results. 


\section{Research Methodology and Sample Selection}

\subsection{Research Methodology}

To examine the hypothesis regarding the effect of AAOIFI governance disclosure on IBs performance $(\mathrm{H} 1)$, the research controls several CG characteristics and firm characteristics following previous studies (Almoneef and Samontaray 2019). The following OLS regression model was used to test the impact of AAOIFI governance disclosure on IBs performance as used in the previous study, to examine the relationship between CG and firm performance (Farhan et al., 2017; Almoneef and Samontaray, 2019). ROA and ROE are used to measure the IBs performance as these are the most widely used by researchers (Almoneef and Samontaray, 2019; Othman, 2014).Table I outlines the definition and measurement of each variable.

Bank performance $=\beta_{0}+\beta_{1} X_{1}+\beta_{2} X_{2}+$ $\beta_{21} \mathrm{X}_{21}+\varepsilon$

Where:

The bank performance will be measured by ROA and ROE

$\beta_{1}=$ independent variables (CGD score in IBs) (Appendix 1\&2)

$\mathrm{B}_{2}-\beta_{21}=$ control variables 
TABLE I :

A SUMmaRY OF DEPENDENT, INDEPENDENT AND CONTROL VARIABLES, DEFINITIONS AND MEASUREMENTS THAT ARE USED TO EXAMINE FIRM PERFORMANCE

\begin{tabular}{|c|c|c|}
\hline Variable & Definition & Measurement \\
\hline $\mathrm{ROA}$ & Return on asset & $\begin{array}{l}\text { Net income dividend by total } \\
\text { assets }\end{array}$ \\
\hline ROE & Return on equity & $\begin{array}{l}\text { Net income divided by total } \\
\text { equity }\end{array}$ \\
\hline $\mathrm{X}_{1}$ & $\begin{array}{l}\text { (CGD) } \\
\text { The quantity of AAOIFI } \\
\text { governance score by IBs }\end{array}$ & $\begin{array}{l}\text { The percentage of AAOIFI } \\
\text { governance information } \\
\text { disclosure by IBs }\end{array}$ \\
\hline$X_{2}$ & Board independence & $\begin{array}{l}\text { The proportion of } \\
\text { independent non-executive } \\
\text { directors on the board }\end{array}$ \\
\hline$X_{3}$ & Board size & Number of board members \\
\hline $\mathrm{X}_{4}$ & $\begin{array}{l}\text { The frequency of directors } \\
\text { meetings }\end{array}$ & $\begin{array}{l}\text { The total number of } \\
\text { directors' meetings during } \\
\text { the year }\end{array}$ \\
\hline$X_{5}$ & Duality in position & $\begin{array}{l}1 \text { = chairman and CEO are } \\
\text { different; } \\
0 \text { = chairman and CEO are } \\
\text { the same }\end{array}$ \\
\hline$X_{6}$ & ACS & $\begin{array}{l}\text { The total number of } A C \\
\text { members }\end{array}$ \\
\hline $\mathrm{X}_{7}$ & Firm size & $\begin{array}{l}\text { The natural logarithm of the } \\
\text { firm's total assets }\end{array}$ \\
\hline X8 & Firm liquidity & $\begin{array}{l}\text { Current ratio = current total } \\
\text { asset to the current total } \\
\text { liability }\end{array}$ \\
\hline$X_{9}$ & Firm leverage & $\begin{array}{l}\text { Long-term debt to total } \\
\text { equity }\end{array}$ \\
\hline$X_{10}$ & Firm asset growth & $\begin{array}{l}\text { Firm asset-growth ratio }= \\
(\mathrm{P} 2-\mathrm{P} 1) / \mathrm{P} 1\end{array}$ \\
\hline$X_{11}-X_{13}$ & Year dummy & $\begin{array}{l}\text { The year 2013, } 2014 \text { and } \\
2015\end{array}$ \\
\hline$X_{14}-X_{21}$ & Country dummy & $\begin{array}{l}\text { All eight countries in the } \\
\text { sample }\end{array}$ \\
\hline
\end{tabular}




\subsection{Sample and Data}

The sample includes all IBs that have mandatorily adopted AAOIFI standards. There are ten countries that have mandatorily adopted AAOIFI standards: "Bahrain, Syria, Qatar, Sudan, Tunisia, Jordan, Lebanon, Palestine, Oman and Mauritius" (Al Qamashoui and Hussainey, 2016). However, the study excludes IBs in Lebanon, Tunisia and some banks from Sudan, because the researchers did not have access to these banks' annual reports. The researcher's aim was to gather annual reports from years 2011 onwards to extend the IBs performance data, but they did not find annual reports for years 2011 and 2012 for a large sample of IBs. Thus, the study started analysis from 2013 to 2015 as it was the most recent year at the time of the analysis.

\section{Results}

\subsection{Descriptive analysis}

Table II shows the outline of the descriptive statistics gained from applying the paradigm to the research question. Here, ROA and ROE are the dependent variables, AAOIFI governance disclosure is the independent variable, and the remaining parameters are control variables.

TABLE II . DesCRIPTIVE STATISTICS OF THE CONSEQUENCE OF AAOIFI GOVERNANCE DISCLOSURE

\begin{tabular}{|c|c|c|c|c|c|}
\hline & $\mathrm{N}$ & Minimum & Maximum & Mean & Std. Deviation \\
\hline ROA & 126 & -30.35 & 22.28 & .94 & 5.971 \\
\hline ROE & 126 & -40.56 & 22.28 & 7.75 & 13.56 \\
\hline Disclosure level & 126 & .035 & .69 & .33 & .164 \\
\hline Frequency of board meeting & 83 & 2 & 10 & 5.73 & 1.616 \\
\hline CEO & 123 & 0 & 1 & .98 & .155 \\
\hline ACs & 84 & 3 & 6 & 3.33 & .567 \\
\hline Liquidity & 126 & .00 & 73.5 & 4.157 & 12.227 \\
\hline Firm size & 126 & 7.33 & $22,893.2$ & $2,378.9$ & $4,090.82$ \\
\hline Asset growth & 124 & -34.96 & 118.07 & 15.614 & 22.98 \\
\hline Leverage & 126 & .00 & 399.7 & 22.79 & 66.93 \\
\hline Board independence & 123 & $0.00 \%$ & $100.00 \%$ & $25.2846 \%$ & $30.19459 \%$ \\
\hline Board size & 124 & 3 & 16 & 8.92 & 2.247 \\
\hline
\end{tabular}


As per the descriptive statistics in Table II, the mean value of the ROA variable is .94, with a minimum value of -30.35 and a maximum value of 22.28 . This mean value is higher than the value of .031 for several Chinese-listed firms in a study by Molnar et al. (2017) and also higher than the value of .016 obtained for some companies listed on the Palestinian Stock Exchange in a study by Hassan et al. (2016). For the variables of ROE, the mean value is 7.75. This mean value is lower than the value of 15.82 for five companies in Nigeria in research carried out by Falaye and Oloyede (2017). However, it is higher than the value of .1487 for some Islamic and non-Islamic banks in the GCC region in a study by Chazi et al. (2018).

The mean value of the level of AAOIFI governance disclosure is 33\%. This means that $33 \%$ of the AAOIFI governance disclosure items in the checklist are disclosed, on average, per annual report. The minimum value is .035 , and the maximum value is .70 for the disclosure level. This indicates that several annual reports are disclosing very little information (approximately $3.5 \%$ of the AAOIFI governance disclosure items), whereas others disclose much more (70\% of the AAOIFI governance disclosure items). This reveals that the level of AAOIFI governance disclosure in IBs is weak. This may be due to the fact that AAOIFI governance is not mandatory.

Regarding control variables, the average value of board independence is .25. Table II shows the lowest value for independent managers is 0.00 , with the greatest value being $100 \%$. This indicates that some IBs do not have independent directors such as the Liquidity Management Centre in Bahrain, while for others all members are independent directors, for instance, Bank Nizwa in Oman.

The Pearson correlation analysis has been completed and suggests that no variable exhibits the problem of multicollinearity. Furthermore, a test for multicollinearity is done by calculating the VIF after each regression model. Based on previous studies (Field, 2009a; Gujarati, 2003), if the VIF value is further than 10, there is a multicollinearity problem. The outcomes in Tables III and IV present the VIF values that are higher than 1 but less than ten; as a consequence there are no multicollinearity problems in this study. In addition, since the number of IBs is just 42 , the normality must be examined. The level of normality can be checked by the graphical method; normality plots have been employed in the current study. The graphical method used to test normality suggests that error is normally distributed, which is considered to be necessary when carrying out hypotheses testing on regression parameters.

In addition, the researchers checked the heteroscedasticity problem by using the BreushPagan test and the outcomes of this test showed that the $\mathrm{P}$ value is .165 which is greater than .05. Therefore, this result indicates that the current data does not have a heteroscedastic problem. From all the above results, the researchers decided to use the OLS regression.

\subsection{Regression analysis}

Tables III and IV show the empirical analysis of the impact of AAOIFI governance disclosure on bank performance. Table III used ROA as a dependent variable and the F-value of 2.721 (.003). The model is found to be statistically significant overall. The adjusted $\mathrm{R}^{2}$ value of .292 (29\%) indicates that the independent variables explain $29 \%$ of the variation regarding the impact of AAOIFI governance disclosure on bank performance. This proportion is less than 56\%, reported by Hassan et al. (2016) but higher than the $20 \%$ reported by Chazi et al.(2018). In addition, it is important to check the Durbin-Watson 
autocorrelation: the Durbin-Watson statistic is always between 0 and 4, but the value in the current study is 1.614 , which means there is no autocorrelation in the sample.

While Table IV used ROE as a dependent variable and gave the F-value of 3.835 (.000), the model is found to be statistically significant overall. The adjusted $\mathrm{R}^{2}$ value of $.547(55 \%)$ indicates that the independent variables explain $55 \%$ of the variation regarding the impact of AAOIFI governance disclosure on bank performance level of AAOIFI governance disclosure. The result is higher than the 1\% reported by Khan et al. (2017) and 5\% reported by Ogege and Boloupremo (2014). As before, it is important to check the Durbin-Watson autocorrelation: the value in the current study is 2.075 , which means there is no autocorrelation in the sample.

Table III shows a statistically insignificant relationship between AAOIFI governance disclosure and bank performance measured by ROA. This result highlights that the level of AAOIFI governance disclosure does not affect the IBs performance measured by ROA. This confirms the findings of Almoneef and Samontaray (2019), who found no significant relationship between audit committee size and is independent of audit committee and bank performance. Similarly, Owen and Temesvary (2017) found that the board gender diversity was insignificant in relationship to bank performance.

However, the results are contrary to those obtained by Albawwat and Hussein (2015), which indicate that the quality of voluntary disclosure appears to have a high correlation with the performance of companies, and also to the findings of Foyeke et al (2015), who investigated this relationship in companies in Nigeria and who also established a significant positive association between bank performance and CG disclosure. Similarly, (Albarak and Elhalaby, 2019), found that Sharia governance has a positive impact on IBs measured by ROA.

The findings of the regression analysis for Table IV also found a statistically insignificant relationship between AAOIFI governance disclosure and bank performance measured by ROE. This indicates that the level of AAOIFI governance disclosure does not affect the IBs performance measured by ROE. This outcome is in line with the findings of Shahid et al. (2018), who found that board size has insignificant relationship with firm performance measured by ROE. On the other hand, (Hassan et al., 2009) found this highly significant, but there was a negative association between the two variables.

The results in Tables III and IV show that there is an insignificant relationship between AAOIFI governance disclosure and ROA/ROE at any significant level. Therefore, hypothesis $\mathrm{H} 1$, which expected a positive relationship between AAOIFI governance disclosure and IBs performance, is rejected. To explain this unexpected result, the researchers looked at the relationship between IBs performance and other control variables. In the regression analysis, as outlined in Tables III and IV, it shows that there is a significant negative relationship between bank performance and board independence, which indicates that having a higher proportion of independent directors across the board, will not improve the overall level of CG disclosure. This outcome is in disagreement with Al-Najjar (2014), who found that board independence is positively related to bank performance, and also Bravo and Reguera-Alvarado (2017), who examined the relationship between board independence and bank performance in US-listed firms. They found that board independence positively influences firm performance.

With regard to other control variables in both regression results, four out of a total of nine were found to be statistically significant, namely board independence, board size, asset growth and leverage. The other five variables, namely board meeting, CEO, ACs, firm size and liquidity, were found to be statistically insignificant. 
According to the test above, we did not find any significant relationship between bank performance and AAOIFI GC disclosure in IBs that mandatorily adopt AAOIFI standards. This result indicates that AAOIFI governance disclosure does not affect bank performance in IBs. This result is inconsistent with Albarak and El-halaby, (2019) who found Sharia compliance has significant impact on IBs performance. From the researcher's viewpoint, the main reason for this result is most likely because IBs aim to be compliant with Sharia principles, to have an active role in the community and to deliver exceptional value to clients and shareholders by focusing on Sharia compliance. Moreover, IBs focus on being an effective corporate citizen and accepting their social responsibility to help develop the community, more than on how to make a profit.

Regarding CG variables generally, the research finds that the best governance drives towards higher bank performance. Particularly, board size has a positive and significant impact on bank performance. Furthermore, the other CG characteristics have shown no significant relationship with bank performance. In practical terms, regarding firm-specific characteristic variables, this outcome presents that asset growth is positively connected with bank performance, as shown in Tables III and IV.

However, the study found no significant association between liquidity, firm size and bank performance. This might be due to the fact that one of the key aims of accounting and reporting, from an Islamic viewpoint, is to ensure that the business is accountable and adheres to Islamic principles (Sharia) (Maali et al., 2006).

With regard to year and country dummy variables, the results in Table III show that all these are an insignificant with respect to IBs performance. This result indicates that IBs performance is not affected by year or country dummy measured by ROA. While the result in Table IV highlights that Qatar is significant at 1\% level of significance with IBs performance measured by ROE. Therefore, ROE is different in Qatar when compared with other countries that adopt AAOIFI mandatorily. This result may be due to IBs in Qatar playing an important role in fuelling the Qatar vision 2030 schedule.

The above results could be beneficial for IBs and may help and encourage them to disclose more information in their annual reports, especially information related to CG. In addition, our results suggest that AAOIFI members should enforce AAOIFI governance standards like other AAOIFI standards (Accounting and Auditing) which are already compulsory in IFIs that adopt AAOIFI mandatorily. Furthermore, this study focuses on IBs only; further research could examine other IFIs. Further research could study other variables that could impact IBs performance such as: number of branches, liquidity and financial development indicators. Also, it would be good to employ other firm performance measures, such as profit margin.

TABLE III. REgRESSION RESUlt: ConsequenCES OF AAOIFI GoVERnANCE DISCLOSURE (ROA) 


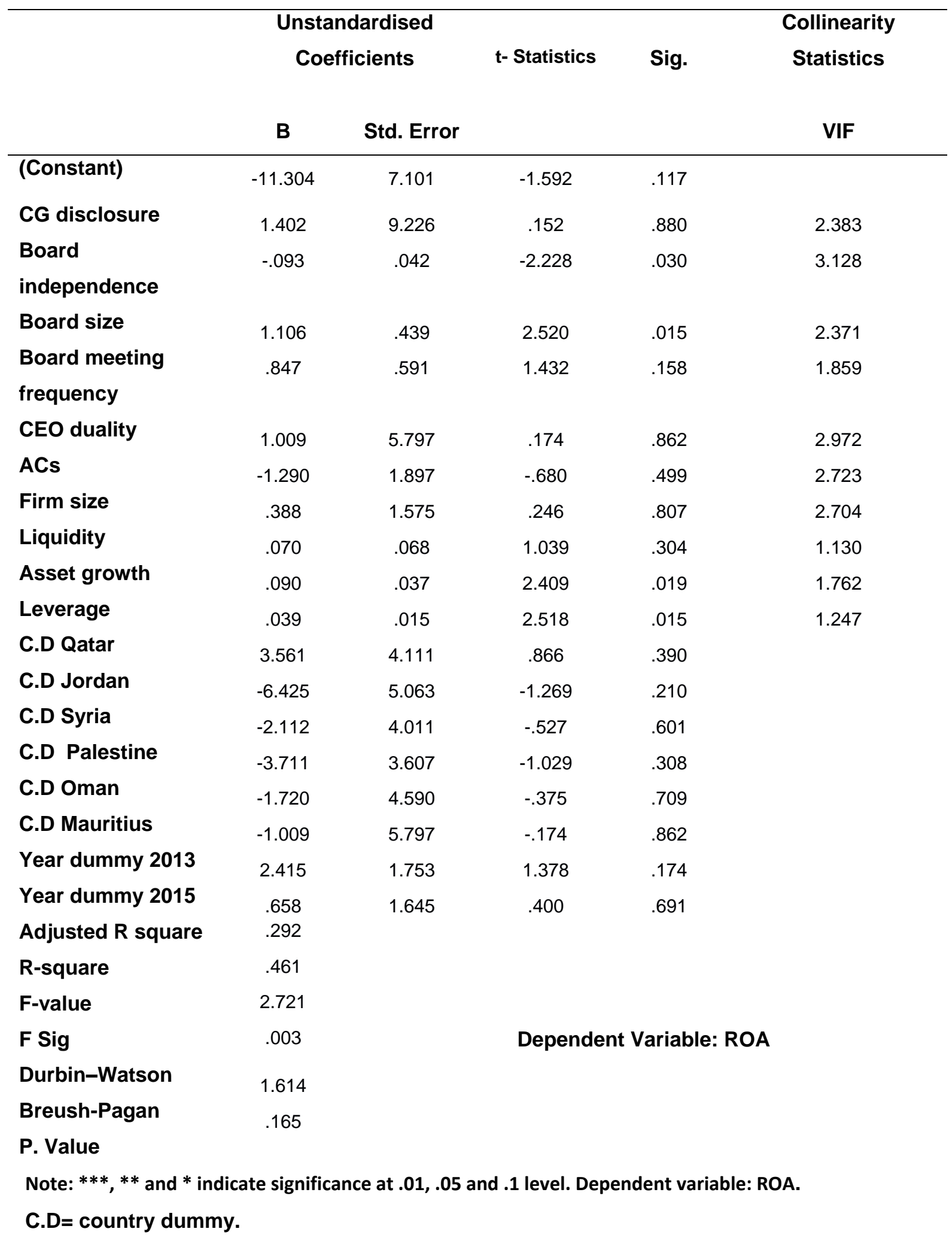

TABLE IV. Regression Result: ConsequenCES of AAOIFI GovernANCE Disclosure (ROE) 


\begin{tabular}{|c|c|c|c|c|c|}
\hline & \multicolumn{2}{|c|}{$\begin{array}{c}\text { Unstandardised } \\
\text { Coefficients }\end{array}$} & \multirow{2}{*}{$\begin{array}{c}\text { t- } \\
\text { Statistic }\end{array}$} & \multirow[t]{2}{*}{ Sig. } & \multirow{2}{*}{$\begin{array}{c}\text { Collinearity } \\
\text { Statistics } \\
\text { VIF }\end{array}$} \\
\hline & B & Std. Error & & & \\
\hline (Constant) & -1.946 & 11.933 & -1.63 & .871 & \\
\hline CG disclosure & -11.719 & 15.503 & -.756 & .453 & 2.383 \\
\hline \multicolumn{5}{|l|}{ independence } & 3.128 \\
\hline Board size & 1.225 & .737 & -1.658 & .102 & 2.371 \\
\hline $\begin{array}{l}\text { Board meeting } \\
\text { frequency }\end{array}$ & .463 & .994 & .466 & .643 & 1.859 \\
\hline CEO duality & -2.420 & 9.741 & -.248 & .805 & 2.972 \\
\hline ACs & -2.847 & 3.187 & -.893 & .376 & 2.723 \\
\hline Firm size & 3.425 & 2.647 & 1.294 & .201 & 2.704 \\
\hline Liquidity & .092 & .114 & .811 & .421 & 1.130 \\
\hline Asset growth & .161 & .062 & 2.575 & .013 & 1.762 \\
\hline Leverage & -.054 & .026 & -2.064 & .044 & 1.247 \\
\hline C.D Qatar & 13.023 & 6.908 & 1.885 & .065 & \\
\hline C.D Jordan & -2.811 & 8.508 & -.330 & .742 & \\
\hline C.D Syria & 13.922 & 6.740 & 2.066 & .044 & \\
\hline C.D Palestine & 5.045 & 6.062 & .832 & .409 & \\
\hline C.D Oman & -6.293 & 7.714 & -.816 & .418 & \\
\hline C.D Mauritius & 2.420 & 9.741 & .248 & .805 & \\
\hline Year dummy 2013 & 1.859 & 2.946 & .631 & .531 & \\
\hline Year dummy 2015 & 2.741 & 2.765 & .991 & .326 & \\
\hline Adjusted R-square & .404 & & & & \\
\hline R-square & .547 & & & & \\
\hline F-value & 3.835 & & & & \\
\hline F Sig & .000 & & Dependent & able: I & \\
\hline Durbin-Watson & 2.075 & & & & \\
\hline
\end{tabular}




\subsection{Endogeneity Problems}

Endogeneity is a problem that occurs when looking at the effect of CG on voluntary CG disclosure and financial performance of firms (Ammann et al., 2011). It can be said that endogeneity occurs if the dependent and explanatory variables have a high correlation with error terms when using multiple regression analysis (Ntim et al., 2012). Based on previous studies, three essential factors can explain the reasons for endogeneity in the regression model: 1. measurement errors; 2. omitted variables; and 3. simultaneity (Ntim et al., 2012; Ammann et al., 2011). So, endogeneity could be seen as a threat if it is caused by a weak econometric model (Larcker and Rusticus, 2010). The current study employed a lagged structure to address endogeneity problems.

\subsubsection{Lagged Structure and Consequences of AAOIFI Governance Disclosure}

This subsection shows the results from both the lagged and the unlagged paradigms to investigate the association between AAOIFI governance disclosure and bank performance. Panel A in Table V presents the outcomes according to the unlagged framework, while panel $B$ presents the estimated lagged framework model (for both accounting measurements: ROA and ROE).

Firstly, panels A and B report the outcomes gained from the unlagged and lagged structure paradigms, respectively, to investigate the impact of AAOIFI governance disclosure and ROA. Particularly, the outcomes present a huge likeness in statistical importance and volume, with little change in some of the control variables. The ratio of independent managers shows a negative and significant association with ROA in both models. However, board size is positive and significant in the first model while insignificant in the second model (lagged). Moreover, the frequency of board meetings was found to be positive and significant in the first model (unlagged) but positive and insignificant, with ROA, in the second model (lagged).

The coefficients and magnitudes of firm characteristic variables for unlagged and lagged framework models seem to be similar. Specifically, asset growth shows a significantly positive relationship with ROA in both models. Leverage is significantly and positively related to ROA in the unlagged structure model, while it is insignificantly related to ROA in the second model (lagged). The adjusted $\mathrm{R}^{2}$ is similar in both model panels (A and B) and shows that $\mathrm{R}^{2}$ is $29 \%$ and $23 \%$ in the unlagged and lagged structure respectively. This implies that $29 \%$ of the variation can be explained by the examined variables.

The F-value is 2.721 and 1.844 at a $1 \%$ level of significance in the unlagged and lagged structures respectively. This similarity in the outcomes confirms that the results gained in the major paradigm are robust, and suggest that the level of AAOIFI governance disclosure in IBs that adopt AAOIFI standards as mandatory, does not affect bank performance measured by ROA.

Secondly, regarding the ROE rate, panels A and B in Table V highlight that the outcomes from the unlagged and lagged framework paradigm are comparatively similar, with little change in the control variables. Regarding the explanatory variable, CG disclosure shows a negative and insignificant relationship to ROE in both models. The expected result for all variables is for leverage to show similar coefficients and magnitudes. There is some likeness for the adjusted $\mathrm{R}^{2}$ between the unlagged and lagged framework, at approximately $40 \%$, while it is $26 \%$ in the estimated lagged framework. The F-value is 3.835 in the unlagged 
framework paradigm and 2.009 in the lagged framework model, both at a $1 \%$ level of significance. This further supports the robustness of the consequences of the AAOIFI governance disclosure paradigm.

TABLE V . REgRESSION RESUltS OF ESTIMATED StRICTURE FOR ConSEQUENCES OF AAOIFI GOVERNANCE DISCLOSURE

\begin{tabular}{|c|c|c|c|c|}
\hline \multirow{3}{*}{$\begin{array}{l}\text { Independent } \\
\text { Variables } \\
\text { CG disclosure }\end{array}$} & \multicolumn{2}{|c|}{$\begin{array}{l}\text { Panel A: Main regression results - } \\
\text { unlagged structure }\end{array}$} & \multicolumn{2}{|c|}{$\begin{array}{l}\text { Panel B: Estimated lagged structure } \\
\text { regression }\end{array}$} \\
\hline & ROA & ROE & ROA & ROE \\
\hline & $1.402 \quad(.880)$ & $-11.719(.453)$ & $11.060(.321)$ & $-3.345(.862)$ \\
\hline Board independence & $-.093(.030)^{* *}$ & $-.116 \quad(.103)$ & $-.109(.030)^{* *}$ & $-.146 \quad(.089)^{*}$ \\
\hline Board size & $1.106(.015)^{* *}$ & $1.225(.102)$ & .758 (.135) & $.886 \quad(.311)$ \\
\hline Frequency of board meetings & $.874 \quad(.158)$ & $.463 \quad(.643)$ & $1.441(.050)^{* *}$ & $1.548 \quad(.217)$ \\
\hline CEO duality & $1.009(.862)$ & $-2.420(.805)$ & $-1.744(.783)$ & $-8.103 \quad(.465)$ \\
\hline Audit committee size & $-1.290(.499)$ & $-2.847(.376)$ & $-1.767(.379)$ & $-2.820(.420)$ \\
\hline Firm size & $.388 \quad(.807)$ & $3.425(.201)$ & $1.828(.332)$ & $4.260 \quad(.197)$ \\
\hline Liquidity & $.070 \quad(.304)$ & $.092 \quad(.421)$ & $.054 \quad(.534)$ & $.118 \quad(.435)$ \\
\hline Asset growth & $.090(.019)^{* *}$ & $.161(.013)^{* *}$ & $.112(.026)^{* *}$ & $.186(.033)^{* *}$ \\
\hline Leverage & $.039(.015)^{* *}$ & $-.054(.044)^{* *}$ & $.057(.404)$ & $.032 \quad(.789)$ \\
\hline Year dummies & Included & Included & Included & Included \\
\hline Country dummies & Included & Included & Included & Included \\
\hline Constant & -11.304 & 1.946 & -12.545 & -4.650 \\
\hline Durbin-Watson statistics & 1.614 & 2.075 & 2.555 & 2.026 \\
\hline F-value & $2.721 * * *$ & $3.835 * * *$ & $1.844 * * *$ & $2.009 * * *$ \\
\hline Adjusted $R^{2}$ & .292 & .404 & .231 & .264 \\
\hline
\end{tabular}

Notes: P-values are in parentheses. $* * *, * *$ and $*$ denote significance at the $1 \%, 5 \%$ and $10 \%$ levels of significance respectively. Chapter 4 gave a specific introduction of the measurement process of overall the variables employed. 2013 is introduced as a one-year lag. 


\section{Conclusion}

This research seeks to examine the impact of AAOIFI governance disclosure on IBs performance. The years of the study were 2013 to 2015 and involved 126 banks, including all IBs that have adopted AAOIFI's mandatory standards. In this paper, the AAOIFI governance disclosure index, structured in the prior paper (Elgattani and Hussainey, 2020), is used as an independent variable. ROA and ROE are used as measures of financial performance; the CG characteristics and firm mechanisms are used in this paradigm as control variables, which consider the most significant factors for CG disclosure and financial performance relationship.

The main contribution of this paper is that it offers the first empirical evidence of the impact of AAOIFI governance disclosure in IB performance. The study found that the association between AAOIFI governance disclosure and financial performance is statistically insignificant in both of the models. This result is inconsistent with the hypothesis and argued theoretical framework. Therefore, it can be seen that a high level of AAOIFI governance disclosure does not affect the performance of IBs. The reason for this outcome might be due to the reality that the main aim of IBs is to comply with Sharia principles, to have an active role in the community, and to deliver the expectation of value to clients and shareholders by focusing on Sharia compliance, more than just making a profit. Also, this may be because other factors such as SSB characteristics or corporate social responsibility disclosure, impact the IBs performance more than AAOIFI governance disclosure.

The practical implications in this study may help IBs and encourage them to disclose more information in annual reports, not just information related to Sharia compliance but information related to AAOIFI governance standards, because following good CG leads to good financial performance and reduces the risk which can result from financial distress. Also, our result could support AAOIFI members through enforcement of AAOIFI standards in IBs that adopt AAOIFI mandatorily, to ensure IBs complete compliance with Sharia and provide good products and services to all stakeholders. This is to clarify the essential competitive advantages for IBs which lead to a higher level of performance.

This study has a number of limitations, such as its focus on two measurements of bank performance, ROA and ROE. It would be good to employ other firm performance measures, such as profit margin measures. Another further direction could be regarding the test of the association between AAOIFI governance disclosure and the reputation of IBs. Also, the sample used in the current study draws on only 126 annual reports over three years, because of the difficulties in collecting more annual reports at the time of the analysis. Therefore, further research could be to conduct the study over more years. Finally, this study focuses on IBs only, further research maybe to examine other IFIs. Further research could study other variables that could impact IBs performance such as, number of branches, liquidity and financial development indicators. 


\section{References}

Abdullah, W. A. W., Percy, M. and Stewart, J. (2015) 'Determinants of voluntary corporate governance disclosure: Evidence from Islamic banks in the Southeast Asian and the Gulf Cooperation Council regions', Journal of Contemporary Accounting \& Economics, 11(3), 262-279.

Aggarwal, R., Erel, I., Stulz, R. and Williamson, R. (2008) 'Differences in governance practices between US and foreign firms: Measurement, causes, and consequences', The Review of Financial Studies, 22(8), 3131-3169.

Albassam, W. (2014) 'Corporate governance, voluntary disclosure and financial performance: An empirical analysis of Saudi listed firms using a mixed-methods research design', unpublished thesis University of Glasgow.

Almoneef, A. and Samontaray, D.P., (2019) 'Corporate governance and firm performance in the Saudi banking industry'. Banks \& bank systems, (14, Iss. 1), pp.147-158.

Al-Akra, M. and Ali, M. J. (2012) 'The value relevance of corporate voluntary disclosure in the Middle-East: The case of Jordan', Journal of Accounting and Public Policy, 31(5), 533 549.

Al-Ataibi, M. H. (2017) 'The role of good institutional governance in the financial performance of companies" Kuwait as a model', Archives of Business Research, 5(12), 1434.

Al-Maghzom, A., Hussainey, K. and Aly, D. A. (2016) 'Corporate Governance and Risk Disclosure: Evidence from Saudi Arabia', Corporate Ownership and Control Journal, 13(2), 145-166.

Al-Najjar, B. (2014) 'Corporate governance, tourism growth and firm performance: Evidence from publicly listed tourism firms in five Middle Eastern countries', Tourism Management, 42, 342-351.

Al-Najjar, B. and Al-Najjar, D. (2017) 'The impact of external financing on firm value and a corporate governance index: SME evidence', Journal of Small Business and Enterprise Development, 24(2), 411-423.

Albarrak, H. and El-Halaby, S. (2019) 'AAOIFI governance standards: Sharia disclosure and financial performance for Islamic banks. Journal of governance \& regulation', (8, Iss. 1), pp.19-37.

Albawwat and Hussein, A. (2015) 'Corporate Governance and Voluntary Disclosure of Interim Financial Reporting in Jordan', Journal of Public Administration and Governance, 5(2), 100-127.

Allegrini, M. and Greco, G. (2013) 'Corporate boards, audit committees and voluntary disclosure: Evidence from Italian listed companies', Journal of Management \& Governance, 17(1), 187-216.

AlQamashoui, A. and Hussainey, K. (2016) 'Determinants of AAOIFI/IFRS Adoption in Islamic Banking Industry', Portsmouth-Fordham Conference on Banking \& Finance, September 2016, Portsmouth Business School, Portsmouth University, UK. 
Ammann, M., Oesch, D. and Schmid, M. M. (2011) 'Corporate governance and firm value: International evidence', Journal of Empirical Finance, 18(1), 36-55.

Amoateng, A. K., Osei, K. T., Ofori, A. and Gyabaa, E. N. (2017) 'Empirical Study on The Impact of Corporate Governance Practices on Performance: Evidence From SMEs In An Emerging Economy', European Journal of Accounting Auditing and Finance Research, 5(8), $50-61$.

Anis, M., Chizema, A., Lui, X. and Fakhreldin, H. (2017) 'The Impact of Board Characteristics on Firms Financial Performance-Evidence from the Egyptian Listed Companies', Global Journal of Human-Social Science Research, 17(5), 57-75.

Bahari, N. F. and Baharudin, N. A. (2016) ' Shariah Governacne Framework:The Roles of Shariah Review and Shariah Auditing', Proceeding of the 3rd International Conference on Management \& Muamalah. (pp. 375-381).

Bhatt, P. R. and Bhatt, R. R. (2017) 'Corporate Governance and Firm Performance in Malaysia', Corporate Governance: The international journal of business in society', 17(5), 896-912.

Black, B. S., Jang, H. and Kim, W. (2006) 'Does corporate governance predict firms' market values? Evidence from Korea', Journal of Law, Economics, and Organization, 22(2), 366413.

Blackburn, V. L. (1994) 'The effectiveness of corporate control in the US', Corporate Governance: An International Review, 2(4), 196-202.

Bozec, R. (2005) 'Boards of directors, market discipline and firm performance', Journal of Business Finance \& Accounting, 32(9-10), 1921-1960.

Boyd, B. K. (1995) 'CEO duality and firm performance: A contingency model', Strategic management journal, 16(4), 301-312.

Bravo, F. and Reguera-Alvarado, N. (2017) 'The effect of board of directors on R\&D intensity: board tenure and multiple directorships', R\&D Management, 47(5), 701-714.

Chan, K. C. and Li, J. (2008) 'Audit committee and firm value: evidence on outside top executives as expert-independent directors', Corporate Governance: An International Review, 16(1), 16-31.

Chapra, M.Umer. (2000). 'The Future of Economics: An Islamic Perspective'. Leicester: The Islamic Foundation

Chazi, A., Khallaf, A. and Zantout, Z. (2018) 'Corporate Governance and Bank Performance: Islamic Versus Non-Islamic Banks In GCC Countries', The Journal of Developing Areas, 52(2), 109-126.

Chen, S., Sun, Z., Tang, S. and Wu, D. (2011) 'Government intervention and investment efficiency: Evidence from China', Journal of Corporate Finance, 17(2), 259-271. 
Chou, T.-K. and Buchdadi, A. D. (2017) 'Independent Board, Audit Committee, Risk Committee, the

Meeting Attendance level and Its Impact on the Performance: A Study of Listed Banks in Indonesia', International Journal of Business Administration, 8(3), 24.

Christensen, J., Kent, P., Routledge, J. and Stewart, J. (2015) 'Do corporate governance recommendations improve the performance and accountability of small listed companies?', Accounting \& Finance, 55(1), 133-164.

Detthamrong, U., Chancharat, N. and Vithessonthi, C. (2017) 'Corporate governance, capital structure and firm performance: evidence from Thailand', Research in International Business and Finance, 42, 689-709.

Elgattani, T., Hussainey, K (2020) "The Level of AAOIFI Governance Disclosure in the Annual Reports of Islamic Banks" (Under review) submitted to Journal of Islamic Accounting and Business Research.

Ezat, A. and El-Masry, A. (2008) 'The impact of corporate governance on the timeliness of corporate internet reporting by Egyptian listed companies', Managerial Finance, 34(12), 848867.

Falaye, A. J. and Oloyede, A. J. (2017) 'The impact of board composition and structure on corporate financial performance in Nigeria', Veritas.

Farhan, A., Obaid, S.N. and Azlan, H.,(2017) 'Corporate governance effect on firms' performance-evidence from the UAE'. Journal of Economic and Administrative Sciences.

Fama, E. F. (1980) 'Agency problems and the theory of the firm', Journal of political economy, 88(2), 288-307.

Fama, E. F. and Jensen, M. C. (1983) 'Agency problems and residual claims', The Journal of Law and Economics, 26(2), 327-349.

Fich, E. M. and Shivdasani, A. (2006) 'Are busy boards effective monitors?', The Journal of finance, 61(2), 689-724.

Field, A. (2009a) Discovering statistics using SPSS, Sage publications.

Foyeke, O. I., Odianonsen, I. F. and Aanu, O. S. (2015) 'Firm size and financial performance: A determinant of corporate governance disclosure practices of Nigerian companies', Journal of Accounting and Auditing, 2015, 1.

Garefalakis, A., Dimitras, A. and Lemonakis, C. (2017) 'The effect of Corporate Governance Information (CGI) on Banks' reporting performance', Investment Management and Financial Innovations (IMFI), 14(2), 63-70.

Gordon, I. M., Hrazdil, K. and Shapiro, D. (2012) 'Corporate governance in publicly traded small firms: A study of Canadian venture exchange companies', Business Horizons, 55(6), 583-591. 
Goodstein, J., Gautam, K. and Boeker, W. (1994) 'The effects of board size and diversity on strategic change', Strategic management journal, 15(3), 241-250.

Gujarati, D. (2003) 'Basic econometrics', (4th edition), McGraw-Hill, Boston. United States Military Academy. West Point.

Gujarati, D. N. and Porter, D. C. (2009) 'Basic Econometrics (fifth edition)', NY, McGrawHill, Inc.

Hassan, Y. M., Naser, K. and Hijazi, R. H. (2016) 'The influence of corporate governance on corporate performance: evidence from Palestine', Afro-Asian Journal of Finance and Accounting, 6(3), 269-287.

Hassan, O. A., Romilly, P., Giorgioni, G. and Power, D. (2009) 'The value relevance of disclosure: Evidence from the emerging capital market of Egypt', The International Journal of Accounting, 44(1), 79-102

Hassouna, D., Ouda, H. and Hussainey, K. (2017) 'Transparency and Disclosure as an Internal Corporate Governance Mechanism and Corporate Performance: Egypt's Case', Corporate Ownership and Control Journal. 14 (4-1), pp.182-195

Haniffa, R. and Hudaib, M. (2006) 'Corporate governance structure and performance of Malaysian listed companies', Journal of Business Finance \& Accounting, 33(7-8), 10341062.

Harun, N. I. (2017) 'Corporate Governance and Performance of United Malacca Berhad'. Online at https://mpra.ub.uni-muenchen.de/78381/ .MPRA Paper No. 78381, posted 17 April 2017 13:20 UTC.

Henry, D. (2008) 'Corporate governance structure and the valuation of Australian firms: is there value in ticking the boxes?', Journal of Business Finance \& Accounting, 35(7-8), 912942.

Hodgson, A. and Stevenson-Clarke, P. (2000) 'Accounting variables and stock returns: The impact of leverage', Pacific Accounting Review, 12(2), 37-64.

Hussain, M. A. and Hadi, A. R. A. (2017) 'Corporate governance and firm performance: evidence from CIDB Malaysia', American Journal of Research Communication, 5(12),1-21.

Inchausti, B. G. (1997) 'The influence of company characteristics and accounting regulation on information disclosed by Spanish firms', European Accounting Review, 6(1), 45-68.

Jensen, M. C. (1993) 'The modern industrial revolution, exit, and the failure of internal control systems', The Journal of finance, 48(3), 831-880.

Jensen, M. C. and Meckling, W. H. (1976) 'Theory of the firm: Managerial behaviour, agency costs and ownership structure', Journal of financial economics, 3(4), 305-360. 
Khan, A., Muttakin, M. B. and Siddiqui, J. (2013) 'Corporate governance and corporate social responsibility disclosures: Evidence from an emerging economy', Journal of Business Ethics, 114(2), 207-223.

Khan, H., Hassan, R. and Marimuthu, M. (2017) 'Diversity on Corporate Boards and Firm Performance: An Empirical Evidence from Malaysia', Humanities, 2(1), 1-8.

Klapper, L. F. and Love, I. (2004) 'Corporate governance, investor protection, and performance in emerging markets', Journal of Corporate Finance, 10(5), 703-728.

Larcker, D. F. and Rusticus, T. O. (2010) 'On the use of instrumental variables in accounting research', Journal of accounting and economics, 49(3), 186-205.

Maali, B., Casson, P. and Napier, C. (2006) 'Social reporting by Islamic banks', Abacus, 42(2), 266-289.

Magalhaes, R. and Al-Saad, S. (2013) 'Corporate governance in Islamic financial institutions: the issues surrounding unrestricted investment account holders', Corporate Governance: The international journal of business in society, 13(1), 39-57.

Mahadeo, J. D., Soobaroyen, T. and Hanuman, V. O. (2012) 'Board composition and financial performance: Uncovering the effects of diversity in an emerging economy', Journal of Business Ethics, 105(3), 375-388.

Mashayekhi, B. and Bazaz, M. S. (2008) 'Corporate governance and firm performance in Iran', Journal of Contemporary Accounting \& Economics, 4(2), 156-172.

Mollaha, S. and Zamanb, M. (2015) 'shari'ah Supervision, Corporate Governance and Performance: Conventional vs. Islamic Banks', Journal of Banking and Finance 58, pp.418435.

Molnar, M., Wang, B. and Chen, W. (2017) 'Corporate governance and firm performance in China'. OECD Economics Department Working Papers, No. 1421, OECD Publishing, Paris.

Neifar, S., Salhi, B. and Jarboui, A., (2020) 'The moderating role of Shariah supervisory board on the relationship between board effectiveness, operational risk transparency and bank performance'. International Journal of Ethics and Systems.

Nelson, J. (2005) 'Corporate governance practices, CEO characteristics and firm performance', Journal of Corporate Finance, 11(1-2), 197-228.

Ntim, C. G., Opong, K. K. and Danbolt, J. (2012) 'The Relative Value Relevance of Shareholder versus Stakeholder Corporate Governance Disclosure Policy Reforms in South Africa', Corporate Governance: An International Review, 20(1), 84-105.

Ogege, S. and Boloupremo, T. (2014) 'Corporate governance and financial performance of banks: Evidence from Nigeria', Acta Universitatis Danubius. CEconomica, 10(2),216-230. 
Othman, K. A. M. (2014). Corporate Governance and Firm Performance in Listed Companies in the United Arab Emirates (Doctoral Thesis). College of Business Victoria University of Melbourne, Australia.

Ouma, O. P. (2012) 'The relationship between dividend payout and firm performance: a study of listed companies in Kenya', European Scientific Journal, ESJ, 8(9),199-215.

Owen, A.L. and Temesvary, J., (2018) 'The performance effects of gender diversity on bank boards'. Journal of Banking \& Finance, 90, pp.50-63.

Paino, H., Bahari, A. B. and Bakar, R. A. (2011) 'Shariah, Social Responsibilities and Corporate Governance of the Islamic Banks in Malaysia', Accounting Research Institute Universiti Teknologi MARA Pahang, Malaysia. European Journal of Social Sciences, 23(3), 382-391.

Pearce, J. A. and Patel, P. C. (2017) 'Board of director efficacy and firm performance variability', Long Range Planning, 51(6), 911-926.

Pillai, R. and Al-Malkawi, H.-A. N. (2017) 'On the relationship between corporate governance and firm performance: Evidence from GCC countries', Research in International Business and Finance, 44, 394-410.

Samaha, K., Dahawy, K., Hussainey, K. and Stapleton, P. (2012) 'The extent of corporate governance disclosure and its determinants in a developing market: The case of Egypt', Advances in Accounting, 28(1), 168-178.

Sarea, A. M. and Hanefah, H. M. M. (2013) 'The Need of Accounting Standards for Islamic Financial Institutions', International Management Review, 9(2), 50-59.

Sarea, A. M. (2020) 'The Impact of Islamic Finance on Sustainability Reporting. In Global Approaches to Sustainability Through Learning and Education' (pp. 262-269). IGI Global.

Scafarto, V., Ricci, F., Della Corte, G. and De Luca, P. (2017) 'Board structure, ownership concentration and corporate performance: Italian evidence'. Corporate Ownership \& Control, 15 (1-2), pp.347-359.

Schwartz-Ziv, M. and Weisbach, M. S. (2013) 'What do boards really do? Evidence from

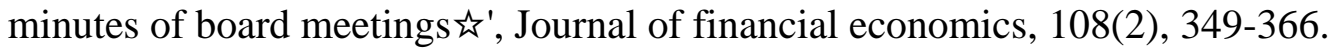

Shahid, M.N., Siddiqui, M.A., Qureshi, M.H. and Ahmad, F.( 2018) 'Corporate governance and its impact on firm's performance: evidence from cement industry of Pakistan'. J. Appl. Environ. Biol. Sci, 8(1), pp.35-41.

Srairi, S. (2015) 'Corporate Governance Disclosure Practices and Performance of Islamic Banks in GCC Countries', Journal of Islamic Finance, 4(2), 001-017.

Taherian, H. and Karampour, A. (2017) 'The impact of corporate governance on the financial performance of listed companies in the Tehran Stock Exchange Chemical industry', Journal of Advances in Computer Engineering and Technology, 3(3), 167-172. 
Upadhyay, A. D., Bhargava, R. and Faircloth, S. D. (2014) 'Board structure and role of monitoring committees', Journal of Business Research, 67(7), 1486-1492.

Vafeas, N. (1999) 'Board meeting frequency and firm performance', Journal of financial economics, 53(1), 113-142.

Velte, P. (2017) 'The link between audit committees, corporate governance quality and firm performance: a literature review', Corporate Ownership \& Control, 14, 15-31.

Vinnicombe, T. (2012) 'A study of compliance with AAOIFI accounting standards by Islamic banks in Bahrain', Journal of Islamic Accounting and Business Research, 3(2), 7898.

White, J. and Ingrassia, P. (1992) 'Board ousts managers at GM; Takes control of crucial committee', The Wall Street Journal, 13(1), 15-31.

Yawson, A. (2006) 'Evaluating the characteristics of corporate boards associated with layoff decisions', Corporate Governance: An International Review, 14(2), 75-84.

Zhang, Y., Zhou, J. and Zhou, N. (2007) 'Audit committee quality, auditor independence, and internal control weaknesses', Journal of Accounting and Public Policy, 26(3), 300-327.

Appendix 1. AAOIFI Governance Index

\begin{tabular}{|l|l|l|}
\hline No. & Governance Standards & No of Items \\
\hline 1 & Sharia Supervisory Board (SSB) & 14 \\
\hline 2 & Sharia Review (SR) & 5 \\
\hline 3 & Internal Sharia Review (ISR) & 8 \\
\hline 4 & Audit and Governance Committee (AGC) for IFIs & 12 \\
\hline 5 & Independence of the Sharia Supervisory Board & 6 \\
\hline 6 & Statement of Governance Principles for IFIs & 11 \\
\hline Total items & 56 \\
\hline
\end{tabular}




\begin{tabular}{|c|c|c|c|c|c|c|c|}
\hline Bank $\quad$ Level of Disclosure & 2013 & 2014 & 2015 & Level of Disclosure & 2013 & 2014 & 2015 \\
\hline 1. Khaleeji Commercial Bank (Bahrain) & $25 \%$ & $25 \%$ & $25 \%$ & 22. Qatar Islamic Bank Doha (Qatar) & $25 \%$ & $25 \%$ & $25 \%$ \\
\hline 2. First Energy Bank $\quad$ (Bahrain) & $50 \%$ & $50 \%$ & $50 \%$ & 23. QINVEST (Qatar) & $16 \%$ & $16 \%$ & $16 \%$ \\
\hline 3. ABC Islamic Bank (Bahrain) & $41 \%$ & $41 \%$ & $41 \%$ & 24. Faisal Islamic Bank Sudan (Sudan) & $18 \%$ & $18 \%$ & $18 \%$ \\
\hline 4. Bahrain Islamic Bank (Bahrain) & $34 \%$ & $34 \%$ & $34 \%$ & 25. Al Shamal Islamic Bank (Sudan) & $21 \%$ & $21 \%$ & $21 \%$ \\
\hline 5. Venture Capital Bank (Bahrain) & $45 \%$ & $45 \%$ & $45 \%$ & 26. Saving \& Social Development Bank (Sudan) & $13 \%$ & $13 \%$ & $7 \%$ \\
\hline 6. Ithmaar Bank (Bahrain) & $54 \%$ & $54 \%$ & $54 \%$ & 27. Farmers Commercial Bank (Sudan) & $20 \%$ & $18 \%$ & $18 \%$ \\
\hline 7. Gulf Finance House (Bahrain) & $27 \%$ & $27 \%$ & $27 \%$ & 28. Al Jazeera Sudanese Jordanian Bank (Sudan) & $20 \%$ & $20 \%$ & $20 \%$ \\
\hline 8. Al Salam Bank of Bahrain (Bahrain) & $48 \%$ & $48 \%$ & $48 \%$ & 29. Tadamon Islamic Bank (Sudan) & $23 \%$ & $23 \%$ & $18 \%$ \\
\hline 9. Bank Alkhair (Bahrain) & $43 \%$ & $43 \%$ & $43 \%$ & 30. Blue Nile Mashreg Bank (Sudan) & $4 \%$ & $4 \%$ & $4 \%$ \\
\hline 10. Albaraka Islamic Bank Bahrain (Bahrain) & $45 \%$ & $45 \%$ & $43 \%$ & 31. United Capital Bank (Sudan) & $9 \%$ & $9 \%$ & $9 \%$ \\
\hline 11. Seera Investment Bank $\quad$ (Bahrain) & $36 \%$ & $36 \%$ & $36 \%$ & 32. Jordan Islamic Bank (Jordan) & $61 \%$ & $52 \%$ & $52 \%$ \\
\hline 12. International Investment Bank (Bahrain) & $36 \%$ & $36 \%$ & $36 \%$ & 33. Islamic International Arab Bank $\quad$ (Jordan) & $45 \%$ & $45 \%$ & $20 \%$ \\
\hline 13. Citi Islamic Investment Bank (Bahrain) & $23 \%$ & $23 \%$ & $23 \%$ & 34. Jordan Dubai Islamic Bank- Renamed to Safwa Islamic Bank (Jordan) & $64 \%$ & $64 \%$ & $68 \%$ \\
\hline 14. Investors Bank (Bahrain) & $41 \%$ & $41 \%$ & $41 \%$ & 35. Syria International Islamic Bank (Syria) & $66 \%$ & $66 \%$ & $70 \%$ \\
\hline 15. Liquidity Management Centre (Bahrain) & $38 \%$ & $32 \%$ & $32 \%$ & 36. Albaraka Bank Syria (Syria) & $11 \%$ & $30 \%$ & $30 \%$ \\
\hline 16. Ibdar Bank (Bahrain) & $48 \%$ & $48 \%$ & $48 \%$ & 37. Cham Bank (Syria) & $7 \%$ & $5 \%$ & $43 \%$ \\
\hline 17. Kuwait Finance House-Bahrain (Bahrain) & $30 \%$ & $30 \%$ & $30 \%$ & 38. Arab Islamic Bank (Palestine) & $45 \%$ & $70 \%$ & $70 \%$ \\
\hline 18. Qatar International Islamic Bank (Qatar) & $13 \%$ & $13 \%$ & $13 \%$ & 39. Palestine Islamic Bank (Palestine) & $39 \%$ & $48 \%$ & $41 \%$ \\
\hline 19. Qatar First Bank $\quad$ (Qatar) & $16 \%$ & $16 \%$ & $16 \%$ & 40. Bank Nizwa (Oman) & $18 \%$ & $50 \%$ & $52 \%$ \\
\hline 20. Barwa Bank (Qatar) & $14 \%$ & $14 \%$ & $14 \%$ & 41. Alizz Islamic Bank (Oman) & $38 \%$ & $50 \%$ & $50 \%$ \\
\hline 21. Masraf Al Rayan (Qatar) & $38 \%$ & $38 \%$ & $38 \%$ & 42. Century Banking Corporation (Mauritius) & $36 \%$ & $41 \%$ & $41 \%$ \\
\hline
\end{tabular}

Appendix 2: Disclosure Level by Bank 